\title{
Economic Conditions for Merchants and Traders at the Border Between Egypt and Nubia in Early Islamic Times*
}

\section{Introduction}

Tenth- and twelfth-century literary sources describe medieval Aswān as a central hub for trade coming through the Red Sea, the Indian Ocean, and the border with Nubia. Mas' $\bar{u}$ di (895-957), for instance, reports that huge caravans full of merchandise from Nubia were transacted in the city. ${ }^{1}$ Arabic letters from Qașr Ibrīm in Lower Nubia emphasize the role of local elites like the Banū al-Kanz in organizing trade in products including spices, dyestuffs, medical substances, and textiles. ${ }^{2}$ However, the early beginnings of this economic success story have yet to be adequately explored. Who were the economic actors and decision makers in the seventh and eighth centuries? To what extent did they draw on traditional networks, and how did production and distribution patterns in the region change over time? The following study can only provide limited insights into these questions. Nonetheless, papyri and archaeological findings dating to the transition period between the late Byzantine and early Islamic period can enhance our knowledge of commercial activity in the border region and the economic objectives pursued by early Muslim rulers. ${ }^{3}$

\section{Muslim influence in Upper Egypt}

The chronology of the Arab conquest of southern Egypt is still understudied and primarily based on literary sources. This explains why reliable information about early Muslim interventions in Aswān's affairs is not easy to obtain. ${ }^{4}$ A study of the Muslim

\footnotetext{
* This paper was written within the framework of the research project 162963 "Change and Continuities from a Christian to a Muslim Society - Egyptian Society and Economy in the 6th to the 8th Centuries" funded by the Swiss National Science Foundation SNSF. I would also like to thank Irene Soto for correcting my English in an earlier version of this paper. All remaining errors are of course my own.

1 Mas'ūdī, Kitāb murūj al-dhahab (C. Barbier de Meynard), III, chapter 33, p. 50.

2 Khan (2013) 148-149.

3 The author of this article is preparing a larger study on the trade networks and production and distribution patterns of Aswān between the fifth and ninth centuries.

4 The traditional view, which centers on the narrations of the Muslim historians, perceives the conquest as a single, unidirectional movement from north to south in which the conquest of Upper Egypt followed that of Babylon, cf. Butler (1902); this is followed in essence by Christides (2012); Fraser
} 
impact on the local economy must thus begin by outlining what we already know about early Muslim activity in southern Egypt and about the main players in the border area at the time.

The first datable evidence of Arab influence in Upper Egypt comes from a papyrus letter in the archive of Papas, pagarch of Edfū (Apollonopolis Magna). It refers to a symboulos 'Abd Allāh and should probably be dated to January $648 .^{5}$ The region (chōra) of Qifț, $150 \mathrm{~km}$ north of Edfū, could have been under Muslim control from as early as 642/643 as Jelle Bruning pointed out in his dissertation citing epigraphic evidence. ${ }^{6}$ Aswān could be reached from Qifṭ after a week-long journey on the Nile, depending on the vessel type, its cargo, and the experience of the crew. ${ }^{7}$

Although the literary sources do not provide details about Muslim activities in this part of the country, they are unanimous in their reports about a military campaign against the Nubians under the first Muslim governor of Egypt 'Amr b. al-'Ạs (first in office 641-645) that ended disastrously for the Muslims. The dominant tradition reports that the fighting took place on Nubian soil. ${ }^{8}$ According to some Muslim historians, however, al-Ṭabarī (838-923), for instance, the Arabs fought against the "Nubians of Egypt" (nūbat mișr); this may be an allusion to Nubian settlers on Egyptian territory in the border region, a thesis that is to a certain extent supported by the archaeological evidence. ${ }^{9}$ Frontier zones very seldom divide two nations strictly from each other; they are more usually zones of contact with often mixed populations. The First Cataract was no exception; ${ }^{10}$ archaeological findings provide ample evidence

(1991); Kaegi (1998); and Kennedy (2008) 139-168. John of Nikiou's chronicle, however, also gives an account of an Arab army coming from the South, and this is considered the most plausible scenario by Booth (2013).

5 P.Apoll. 2 (Edfū; 6 January 648), cf. BL VIII 10. Muslim control of Edfū at that time is also demonstrated by SB Kopt. I 242, a well-known Coptic document concerned with the distribution of pepper among the guilds of the town dated to 649; for Damianos, duke of the Thebaid in 649, cf. CPR XXX 199; Gascou/Worp (1982) 90. However, when the region was conquered is still unclear. At least Edfū could have remained under Byzantine control until January 641, depending on the dating of a regnal formula in the marriage contract SB VI 8986 from that town, cf. Sijpesteijn/Worp (1977) 284; Gonis (2008); Zuckerman (2010) 867-887.

6 Bruning (2018) 92. This interpretation certainly depends on the meaning of chōra in this context, cf. SB Kopt. III 1584.14 (= Brunsch [1994] 30, no. A 14529) of which Van der Vliet (2013) 175- 76 provided a new reading given in translation (chōra = land).

7 Cooper (2014) 156-160.

8 Ibn 'Abd al-Ḥakam (Torrey) 169-170, al-Balādhurī (Ḥitti) 379 (237) and al-Ya'qūbī (Houtsma), vol. II, 179-180 report that 'Amr sent 'Uqba b. Nāfi' b. 'Abd al-Qays al-Fihrī to conquer Nubian land (ard $a l-n \bar{u} b a$ ). Robin Seignobos (forthcoming) 32-42 makes plausible that the common source for this tradition is Ibn Sa'd (d. 845), who again relies on Yazīd b. Abī Habīb (d. 745), a "black Nubian" (aswād $n \bar{u} b \bar{\imath})$, whose father might have been a Nubian captive from Dongola.

9 Al-Ṭabarī (Prym) V, 2593. For this interpretation, cf. Bruning (2018) 94; for the two different narrative chains about a campaign in Nubia or on Egyptian soil with Yazīd b. Abī Ḥabīb (d. 745) as a common source, cf. Seignobos (forthcoming) 36.

10 A good study of the First Cataract as a permeable frontier zone in Islamic times is provided by Seignobos (2010). 
that prestige-good networks, gift exchange, and trade in consumer goods had always generated considerable mobility of people and goods between Nubia and Upper Egypt. Aswān pottery, for instance, has been found all over Lower Nubia, and this reflects the economic exchange of local Egyptian goods in the border region throughout the Roman, Byzantine, and indeed also Islamic periods. ${ }^{11}$ Even domestic architecture was influenced by the neighboring cultures, as archaeological investigations of houses in the area of the First Cataract have demonstrated. ${ }^{12}$ This picture of high interconnectivity is strengthened further by recent archaeological investigations of a site called Qal'at al-Bābayn about $20 \mathrm{~km}$ south of Edfū and ca. $80 \mathrm{~km}$ north of Aswān. ${ }^{13}$ Findings from the site in the mountain range Jabal al-Sirāj revealed a high degree of similarity with pottery, textiles, footwear, and the architectural style of Nubian fortified enclosures in the First Cataract. ${ }^{14}$ Instead of a hard frontier between Egyptians and Nubians, the Arabs in their advance southwards may thus have encountered a scenario with mixed populations closely connected by social and economic networks. ${ }^{15}$

With regard to the situation in Aswān itself, it needs to be conceded that no reliable information exists regarding either the mixed composition of the population or the city's political rulers at the time of the Arab conquest. ${ }^{16}$ Evidence of a Byzantine army presence in the region breaks off in 613, with the last document being a papyrus from the family archive of Patermouthis (493-613), who was a boatman and soldier of Elephantine. ${ }^{17}$ An analysis of what happened with the military unit under the Sa-

11 Adams (2013); Adams (1986). For trade in textiles, cf. Wild/Wild (2014) and a current project conducted by Magdalena Wozniak (National Science Centre $[N C N]$ in Warsaw) which analyzes textile production and consumption in medieval Nubia: http://centrumnubia.org/en/projects/nubian-textiles. 12 See Arnold (2013), who analyzed architecture in the area of the First Cataract from the sixth to the tenth centuries.

13 For this distance, cf. Grossmann (1991), but see also Effland (1999) 50: "14 km südlich von Edfu," and $i d$. (2008) 84 with n. 3: "Die Koordinaten des Ortes lauten $24^{\circ} 48^{\prime} 39^{\prime \prime} \mathrm{N}$ und 32 $54^{\prime} 51^{\prime \prime}$ O." 14 Gascoigne/Rose (2010) 46-47; Effland (1999) 50; Grossmann/Jaritz (1974), in which the pottery was dated to between the fifth and seventh centuries, with some pieces of eighth- or ninth-century origin. But see now Gascoigne/Rose (2010) 46-47 with n. 8-9 who re-date the mixed Egyptian and Nubian pottery to the period between the mid-seventh and the ninth centuries.

15 Studies of the presence of Nubian material culture in southern Egypt, in particular to the north of Aswān, are still only at the beginning, but archaeologists nonetheless emphasize that the southernmost part of Egypt "was substantially penetrated by Nubian cultural influence in early Islamic times," cf. Gascoigne/Rose (2010) 47. The authors point out (p. 49-50) that the "uniqueness" of such sites as Qal'at al-Bābayn could simply be due to a general lack of archaeological investigations of sites like, for instance, the complex of Abū Hība, about $20 \mathrm{~km}$ north of Aswān.

16 The pottery of Aswān, which gives information about economic and intercultural influences, is currently being studied by Gregory Williams (Bonn) in his forthcoming dissertation.

17 The soldiers of a legio of Syene or Elephantine appear as witnesses to documents of the archive, cf. Keenan (1990) and Porten et al. (1996) 398-402, passim. For the military presence in the region in Roman/Byzantine times, cf. also Dijkstra (2008) 28; Maxfield (2000) 413; Brennan (1989); Bowman (1978) and the late antique Notitia Dignitatium orientis XXXI 35; 64-65. 
sanian occupation of Egypt (618/619-629) and, moreover, the question of who filled the vacuum in this strategic border region between the Persian retreat from Egypt in 629 and the Arab invasion of 639 is still a desideratum. ${ }^{18}$ According to the literary sources, Aswān came under Muslim control when governor 'Abd Allāh b. Sa'd b. Abī Sarh (in office 645-656) led the second campaign against Nubia. Ibn Hawqal (d. after 978), recorded that 'Abd Allāh b. Sa'd conquered Aswān, Elephantine, and Philae in $652 .^{19}$

Given the strategic value Aswān as location would have had for the Muslim campaign under 'Amr b. al-'Āṣ, an earlier date is not to be excluded, but neither archaeological nor documentary textual sources provide evidence for this. ${ }^{20}$

\section{Interventions in trade by central authorities}

\subsection{Fostering external trade and traders commuting to and from Nubia}

After these two major campaigns in which the Muslims had failed to gain victory over Nubia, the antagonist parties finally reached a settlement that ended hostilities under the second Muslim governor of Egypt 'Abd Allāh b. Sa'd..$^{21}$ The majority of accounts report that this was achieved by a mutual agreement involving an annual exchange of Nubian slaves for Egyptian goods known as baqt. ${ }^{22}$ Muslim historians focused on defining the legal framework underlying this treaty, for instance, whether it was a truce (hudna) or a peace treaty (șulh). ${ }^{23}$ Comprehensive economic questions,

18 Schmidt (forthcoming) and Seignobos (forthcoming) 27 and n. 55.

19 Ibn Hawqal (Kramers, Wiet) I, 49; Vantini (1975) 153. Some scholars assume that the Arabs had to re-conquer Aswān from the Nubians at that time; cf. Jakobielski/Van der Vliet (2011) 30.

20 The earliest possible trace of Muslim activity in the town may be an Arabic tombstone archived in the Museum of Islamic Art in Cairo, which commemorates the death of a certain 'Abd al-Rahmōn ibn Khaīr al-Ḥajī. However, its origin from Aswān is disputed; cf. El-Hawary (1930); Schmidt (forthcoming).

21 Al-Balādhurī (Hitti) 379 (237); Ibn 'Abd al-Ḥakam (Torrey) 169-170. Ibn Sa'd ('Umar) V, 69-70; VI, 138-139, and al-Ṭabarī (Prym) V, 2593 follow two different narrative chains, but also with the common source Yazīd b. Abì Habīb (d. 745); for a detailed discussion of the chains of narration of the baqț, cf. Seignobos (forthcoming) 59-65. See, moreover, the discussions in Christides (1992); Forand (1972); Hinds/Sakkout (1981); Zaborski, A., "Marginal notes on medieval Nubia," (typewritten essay, 3, quoted after Christides [1992] 345); for an interpretation as tribute, cf. Beshir (1975) 24; for the șulhan/anwatan traditions of the early Islamic jurists, cf. Noth (1973).

22 A compilation of related narrations is given in Vantini (1975) 58 (Ibn 'Abd al-Hakam); 68-69 (Ibn al-Khordādhbeh); 74 (al-Ya'qūbī); 80 - 82 (al-Balādhuri); 91 (Ibn al-Faqīh); 98 (al-Ṭabarī); 105 (Qudāma); 132 (al-Mas'ūdī); 316 (Michael the Syrian); 346 (Yaqūt); 348-349 (Ibn al-Athīr); 420 (Bar Hebraeus); 476 (al-Nuwayrī); 529 and 534-535 (Ibn al-Furāt); 638-646 (al-Maqrīzī); 744 (al-Șuyūṭī). 23 For hudna, cf. Khadduri (2012a); Ibn 'Abd al-Hakam (Torrey) 188; Al-Balādhurī, Futūh (Hitti, 380 381 [238]; for șulh, cf. Khadduri (2012b); Abū 'Ubayd al-Qāsim b. Sallām (Harrās) 215, no. 402. 
like who produced the Egyptian goods for the baqt or to what extent the economies involved benefitted from this diplomatic goods exchange, were not mentioned by the literary sources and have also not been a major focus of the academic discussion of the baqt so far.

The regulations of the baqt were in effect for several hundred years and created a basis for politically supported border trading. This is most effectively demonstrated by means of a famous Arabic papyrus found in Qașr Ibrīm in Lower Nubia. ${ }^{24}$ This long letter (255 cm long and ca. 53,5 cm in width) is part of a dossier of five otherwise Coptic papyri which were stored together in a house, possibly the residence of the eparch of Qașr Ibrīm. ${ }^{25}$ The dossier, which has been dated to between 758 and 759/ 760 , not only proves the historicity of the baqt. The letters also give interesting insights into cross-border commercial activities and their legal implications for traders commuting between the countries. The sender of the Arabic letter was the Egyptian governor Mūsā b. Ka'b (in office 758-759), who wrote to the șāhib of Muqurra and Nubia, probably to be identified with King Cyriacus. ${ }^{26}$ Given that there is no evidence for a royal residence in Qașr Ibrìm, it is assumed that the letter had been forwarded from the king to the eparch in Qașr Ibrīm - perhaps mentioned in the text as "your deputy" (khalifat-ak) -, who stored it together with the Coptic letters for archival purposes. ${ }^{27}$

Written about a hundred years after the conclusion of the baqt, the letter mentions the major points of the mutual arrangement, which was still in force: the annual provision of slaves of good health and right age by the Nubians, the return of escaped slaves and criminals, the freedom of settlement Nubians enjoyed in Egypt, and finally the unimpeded movement and the protection of border-crossing merchants. ${ }^{28}$ Mūsā blamed the Nubian șāhib for the poor quality of the slaves recently furnished. And, moreover, he particularly denounced violations of the freedom of travel of Egyptian traders who entered Nubia for business reasons, complaining that they

24 Hinds/Sakkout (1981) 226 - 229 (= P.HindsNubia = P.AbuSafiyaRisalatMusa [Qașr Ibrīm, 25 November 758]), also discussed in Adams (2010) 246-248; Sijpesteijn (2010) 115-116; Plumley (1975).

25 Adams (2010) 24-25; 244-249; Plumley (1975); Plumley/Adams (1974).

26 For this, see Hinds/Sakkout (1981) 226, commentary to line 2. For the Arabic term șāhib and its use in inner-Egyptian administration, see Morelli (2010) 163: "Ṣāḥib è poi usato effettivamente come titolo amministrativo: șāḥib al-shurța; șāḥib al-barīd, etc.; tutti personaggi di grado elevato a livello provinciale." Sijpesteijn (2013) 103 points out that in Egypt, mostly Christian pagarchs were called șāhib. 27 For the archival purpose, see recently Adams (2010) 245, and 247 for the absence of a royal residence. Plumley (1975) 242 considered the option that the Coptic letters were drafts of a reply. The Coptic letters were dated to the governorship of Muhammad b. al-Ash'ath (in office 759-760), who followed Mūsā b. Ka`b in office; cf. Plumley (1975) 242. The Coptic documents are being studied by Joost L. Hagen in his dissertation. A rough summary is provided in Adams (2010) 245.

28 Regarding the question of settlement, we see major differences to the conditions of the baqt as transmitted by Maqrīzī (Wiet) III.2, 290-292. Maqrīzī (1364-1442) reports that the Nubians were not allowed to settle in Egypt, but only to pass through the country. This may be an indicator that the conditions for the agreement had been altered sometime after 758 . 
were not being adequately protected. He refers to the case of a merchant from Aswān, Muḥammad b. Zayd, whose employee had been maltreated and robbed on Nubian territory. Mūsā calls upon the Nubians to adhere to the compact ('ahd $)^{29}$ both sides were legally bound to and to provide security for the merchants.

The letter reveals, moreover, that the Egyptian governor's deputy with responsibility for Aswān ('āmil 'alā Aswān), who was Salm b. Sulaymān at this time, was the guarantor for the security of the frontier zone on the Egyptian side. ${ }^{30}$ Later literary sources inform us that it was the deputy residing in Aswān who was also responsible for overseeing the transactions of the baqt and the handover of the slaves. Mas 'ùdī, writing in the tenth century, reports that in return for his efforts, the deputy was entitled to take forty slaves annually for his own purposes. The same applied to the assisting judge (al-hâkkim) of the city, who could obtain five slaves, and to the twelve notaries (shāhid 'adūl), who each received one for themselves. ${ }^{31}$ Aswān's administration and legal institutions may thus have profited from the dynamics of exchange under the early Abbasids. The case of Muhammad b. Zayd reveals, moreover, that Muslim merchants at that time had already begun to engage in regional exchange networks. By the middle of the eighth century, Aswān had become a trading place for Muslim merchants who were actively involved in the development of the town's economy. The letters from Qașr Ibrīm, not all of which have been published so far, impressively demonstrate how direct state intervention aimed not only to provide stable conditions for diplomatic, but also for commercial exchanges. The baqt and its accompanying conditions fostering and protecting free trade and the mobility of traders certainly had positive effects on external and on cross-border trade.

\subsection{Taxes affecting traders}

Measures which protected exporting or importing merchants worked first and foremost to the advantage of the commuting merchants. But they must also have been in the financial interests of the Muslim authorities, given that steady flows of imports

29 For 'ahd, cf. Schacht (2012); see Hinds/Sakkout (1981) 214-216 on this issue, who assume that the kind of agreement had been altered from a simple hudna plus an annual exchange of goods to a more complex arrangement by the time of the early Abbasids.

30 Salm must have been in office at least since February 758, because Mūsā mentions his earlier investigation in the case nine months before the letter was written in November; cf. Hinds/Sakkout (1981) 228, 1. 51.

31 Mas' ūdī (Barbier de Meynard) III, 39-40, mentions 365 slaves for the treasury (bayt al-māl). Apart from the slaves for the deputy, the judge, and the notaries in Aswān, forty slaves were intended for the governor (amir) of Egypt. Maqrīzì (Wiet) III.2, 291, mentions 360 "heads" ( $r a$ 's), which were to be handed over to the wāli in Aswān. It is possible that he relies on the lost accounts of Ibn Sulaym alUswānī from Aswān, who wrote between 969 and 975; cf. Hinds/Sakkout (1981) 210; for al-Aswānī, see Kheir (1989). Ibn 'Abd al-Ḥakam (Torrey) 188. 16 to 189.5 transmits two figures: 360 and 400 prisoners (l. 12: ra's min al-sabì), of which 40 were for the wälī. 
and exports would have generated revenue from taxes on trade. The extent to which custom duties could contribute to the state finances is impressively illustrated by what is known of Roman tariffs in the second century. The high tax of 25 percent (tetartēe $)^{32}$ on imports from outside the Empire must have brought significant revenues to the Roman state. This is clearly demonstrated by the Indo-Roman trade of which the so-called Muziris Papyrus from the middle of the second century is a unique example. ${ }^{33}$ The papyrus preserves a record of the goods and the monetary value of a cargo shipped from India to Egypt. The total value, which was already reduced by the amount for the quarter-tax, was 1,151 talents 5,852 drachmae (dr.) (in total: $6,911,852 d r .{ }^{34} .^{34}$ The value of the tetarte for this cargo alone would have been about 2,303,950 dr. ${ }^{35}$

The total amount of revenues from customs in early Islamic Egypt is not known

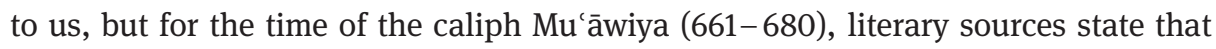
revenues from the river trade amounted to 12 million dinārs. ${ }^{36}$ Central authorities who obtained revenues on trade thus had a strong motive to secure this significant source of income and protect the movements of traders against any kind of threats and uncertainties.

The beginning of Muslim taxation on trade is often ascribed to the period of 'Umar b. al-Khațāāb (634-644). ${ }^{37}$ After he had learned that Muslim merchants had to pay the tithe (ten-percent tax) abroad, it is said that 'Umar decided likewise to levy a sales tax on foreign merchandise. This tax is usually identified with the 'ushr, a tax of ten percent. ${ }^{38}$ The Muslim legal sources, which, however, were produced outside Egypt, report that the rate of the 'ushr differed with regard to the religion of the payers (Muslims or dhimmi, non-Muslims who enjoyed protection since they acknowledged Islamic rule $\mathrm{e}^{39}$ ), their occupation (merchant or cultivator), and their relationship to the Muslim community ( $h a r b i^{40}$ or mu'āhid): The full 'ushr of ten percent was to be levied 1) in kind on Muslim cultivators of land that was irriga-

32 For the 25 percent at the Roman Red Sea port Leuke Kome in PME 19, cf. Wallace (1969) 25; Young (1997); Cottier (2010).

33 SB XVIII 13167; De Romanis (2012); Morelli (2011); Rathbone (2000); Casson (1990); Thür (1987); Harrauer/Sijpesteijn (1985).

34 Morelli (2011) 214 to line 57; the ed. pr. read 1,154 talents 2,852 drachmae.

35 Speidel (2016) 166 pointed out that we may easily expect that one hundred of these ships may have imported goods from India per year, and surmised that the income from customs could have sufficed to cover all military expenses incurred by the Empire in the second century. Not yet included in this calculation are internal tariffs levied for passing custom borders between provinces and cities. For internal tariffs and custom borders, cf. Cottier (2010) 141-148; Jördens (2009) 355-396; Drexhage (1994); Sijpesteijn (1987) 25.

36 Sijpesteijn (2013) 180; al-Dimashqī (Mehren) 109. For metrology, cf. Hinz (1970) 1-2.

37 Yaḥyā b. Ādam (Shemesh) no. 638-639.

38 Becker (1906) 53-56; Darling (2015); Sato (2012).

39 Cahen (2012).

40 Abel (2012). They lived outside Muslim territory, but had permission to trade in Islamic countries. 
ted naturally, and 2) ad valorem on harbì merchants when they crossed the border of a Muslim country (dār al-Islām), for instance, that between Egypt and Nubia. Half the rate of 'ushr (five percent) was paid by 3) Muslim cultivators of land that was irrigated artificially (water wheels, carried water, etc.) and 4) dhimmī merchants. ${ }^{41}$ The latter had to pay the full 'ushr on the value of wine and pork when the merchant passed the station of a tax collector. ${ }^{42}$

In legal sources, 'ushr and maks are often used synonymously. Mukūs (plural) were, however, deplored as illegal impositions throughout most of the Umayyad period and only later became accepted as customs..$^{43}$ In Egypt, maks first appears in two papyri concerned with shortages of grain in 710. In one letter, the governor Qurra b. Sharīk ordered Basileios, the administrator of Aphrodito, to ensure that every täjir (dealer, merchant) in his district brought half of his stored grain (ța'äm) to Fusțāt to sell it on the market. ${ }^{44}$ The superintendent of the maks (șāhib al-maks) in Fusțāt should take notice of the amount of grain being imported and sold in the capital. ${ }^{45}$ That merchants who sold their grain in the capital usually paid maks is revealed by another letter from Aphrodito written in the same period. ${ }^{46}$ The unknown writer, presumably Qurra, declared that he had remitted the maks so that merchants could sell their grain and also make a profit. ${ }^{47}$ Whether this maks was a kind of sales tax or a charge for bringing products into the Fusțāt market remains unclear. The amount of taxes a merchant had to pay until his merchandise finally reached the purchaser was certainly not insignificant. There were fees and customs for entering customs districts and for using roads, bridges, and harbors. A Coptic letter from the Fayyūm concerned with the sale of wine in the eighth century gives an example of at least four different taxes due before a commodity reached Fusțāt: charges at the custom barrier of Arsinoe, a fee to pass the bridge at al-Lāhūn (a village at the eastern entrance to the Fayyūm), an undefined telos, and custom duties at the harbor of Babylon. ${ }^{48}$

41 Yaḥyā b. Ādam (Shemesh) nos. 39; 121; 213; 214-216; 219; 221-222; 639. Abū Yūsuf (Fagnan) 187188; 204-213; Abū 'Ubayd al-Qāsim b. Sallām (Nyazee) nos. 1655-1692.

42 Yahyā b. Âdam (Shemesh) no. 222: "The tax collector has to assess the wine and the hogs, if they are for trade, and collect ten percent of their value." See also no. 37: "They are charged with it but double șadaqa is not charged on others among the ahl al-dhimma, except from their trade when they pass by in front of the collector ("āshir)." And nos. 215-216; 220-221; 223 (wine); 222 (wine and hogs).

43 On the relation and nature of maks and 'ushr, cf. Forand (1966). The Arabic maks presumably derives from the Aramaic $m^{e} k^{e} s \bar{a}$ (toll, tribute, impost, tax), which was translated as Greek telos in the bilingual toll tariff of Palmyra from 137. The decree of the city council of Palmyra is published in De Vogüé (1883) at 162, LI (Greek) and 163, LI, 3 (Aramaic). For mak șā, cf. Fraenkel (1982) 283; Becker (1906), 53-56; Payne Smith (1903) 272.

44 P.Heid.Arab. I 2.16-22 (Aphroditō; 710).

45 P.Heid.Arab. I 2.24-25.

46 P.BeckerNPAF 4 (Aphroditō; 710).

47 P.BeckerNPAF 4.5-6.

48 CPR II 228 v 7-11 (Babylon; VIII). For customs at Babylon, cf. also P.Berl.Frisk. 6 (= SB V 7520) (Aphroditō; 710); P.Lond. V 1754 (Babylon; VII-VIII). 
Already in Roman and Byzantine times, wine had been an important Egyptian trade commodity which was also destined for an external market. This can be assumed from the significant number of Egyptian amphorae found in Nubia. Roman and Late Roman period amphorae from Aswān (R30 and W24) and the Theban region (U4) with resinated interiors have been found in domestic and tavern refuse between the First and Second Cataracts. ${ }^{49}$ Wine continued to be produced and distributed on a considerable scale under Muslim rule. William Y. Adams' study of pottery found in Nubia revealed that the percentage of sherd composition of Aswān U2 amphorae constituted almost 20 percent of the pottery findings in Nubia dated to between 650 and $700 .^{50}$ With regard to the trade in wine, it is worth keeping in mind that according to Islamic regulations, a dhimmi was taxed double his usual tax rate when he traded in this commodity. ${ }^{51}$ Since the tax was not levied on the sale of wine, but on the mere activity of trade, all commercial movements of wine to Nubia must have generated lucrative revenues for the Muslim authorities.

It thus seems entirely plausible to assume that Mūsā b. Ka'b’s (in office 758-759) efforts to facilitate continuous border trade with Nubia did not only serve diplomatic purposes. It is likely that merchants who pursued cross-border trade paid the 'ushr or an equivalent tax, which made external trade, particularly with non-Muslim countries, a lucrative business for the state treasury. ${ }^{52}$

To sum up: The border trade between Aswān and Nubia, especially the question of commuting merchants and goods traded, is fundamentally a story of continuity. Roman and Late Roman trade networks and consumption patterns persisted more than a century after the Arab conquest, as is evidenced by the trade in wine. The baqt and accompanying agreements created favorable terms for a flourishing border trade, which was fostered and secured by the Muslim authorities from the very begin-

49 Adams (1986) 525-560 (“Aswān wares”). The typical red Aswān ware, which was made of pink clay, can be found all over Egypt and the Mediterranean; for Elephantine, cf. Gempeler (1992); for the early Roman period: Rodziewicz (2005); the material from Aswān is being studied i.a. by A. L. Gascoigne, G. Pyke, P. Rose, and G. Williams (dissertation forthcoming). Cf. moreover, the excavation reports in MDAIK 64 (2008) 305-356, at 344-356; MDAIK 52 (1996) 233-349; MDAIK 50 (1994) 115141, at 122-141; for Aswān ware in Edfū, cf. Gascoigne (2005) 161; for Tell Mound (Luxor), cf. Masson et al. (2012) 129-130; for Dayr al-Bakhīt (Thebes West), cf. Beckh (2013) 16-17; 181-183; pl. 69-91; 114-115; for al-Ashmūnein, cf. Bailey (1998) 8-38; for al-Tōd, cf. Lecuyot/Pierrat-Bonnefois (2004) Td 136-150 "W" and Pierrat (1991) 149; 175-192; for al-Quseir: Strange Burke (2007) 81-86; for Alexandria, cf. Rodziewicz (1976).

50 Adams (1986) 540-542 and fig. 305 Z; 545; the index figures on 630.

51 Yaḥyā b. Ādam (Shemesh) nos. 215; 220 -221; 223 (wine); 222 (wine and hogs).

52 The tax of ten percent is perhaps also referred to in an Arabic letter from the Fatimid period found at Qașr Ibrīm; cf. Adams (2013) 251. The sender is a Muslim merchant, writing to the eparch and announcing his upcoming journey to Nubia to the king. However, if the lacuna is indeed to be completed with the ten-percent tax as the editor assumed, it would mean that the Nubians had some share in it: "Send me your letter [permitting] that group of merchants enter [the king's territory] with me; would you treat them well on account of the ... [tenth? i. e. ten-percent tax on goods, possibly]", translated following E. Sartain. 
nings of incipient peaceful relationships between the countries. A strong motivation for a stable border trade was certainly related to the prospect of revenues from taxes levied on goods like the wine destined to be traded or sold to Christian Nubia.

\section{Bibliography}

\section{Primary sources}

Abū 'Ubayd al-Qāsim b. Sallām, Kitāb al-amwāl, Imran A. K. Nyazee (ed.), The Book of Revenue, Reading 2003.

Abū 'Ubayd al-Qāsim b. Sallām, Kitāb al-amwāl, Ḥalil Harrās (ed.), Cairo 1968.

Abū Yūsuf, Kitāb al-kharāj, Edmond Fagnan (ed.), Le livre de l'impôt foncier, Paris 1921.

Al-Balādhurī, The Origins of the Islamic State being a translation from the Arabic accompanied with annotations, geographic and historic notes of the Kitāb futūh al-Buldān, Philip Khūri Hitti (ed. and transl.), New York 1916.

Al-Dimashqī, Nukhbat al-dahr fí 'ajā'ib al-barr wa-l-bahr, August F. Mehren (ed.), Leipzig 1923.

Giovanni Vantini, Oriental Sources Concerning Nubia, Heidelberg 1975

http://www.medievalnubia.info/dev/index.php/Giovanni_Vantini\%27s_Oriental_Sources_Concern ing_Nubia (last accessed 1 November 2017).

Ibn 'Abd al-Ḥakam, Futūḥ Mișr, Charles C. Torrey (ed.), The History of the Conquest of Egypt, North Africa and Spain, New Haven 1922.

Ibn Ḥawqal, Kitāb șūrat al-arḍ, Johannes H. Kramers (ed.), Leiden 1938-1939.

Ibn Sa'd, Kitāb al-Ṭabaqāt al-kabīr, 'Alī Muhammad 'Umar (ed.), 11 vols. (Maktabat Hānǧ̄ī), Cairo 2001.

Al-Maqrīzī, Kitāb al-mawā'iẓ wa-l-i'tibār fĩ dhikr al-khițaț wa-l-āthār, Gaston Wiet (ed.), vols. 5, Cairo 1911-1927.

Al-Mas'ūdī, Kitāb murūj al-dhahab, Charles Barbier de Meynard and Abel Pavet de Courteille (eds.), Les prairies d'or, 9 vols., Paris 1861-77.

Al-Ṭabarī, Ta'rīkh al-rusūl wa-l-mulūk, Michael J. de Goeje et al. (eds.), 16 vols., Leiden 1879-1901.

Yaḥyā b. Ādam, Kitāb al-kharāj, ed. Aharon Ben Shemesh, Taxation in Islam, Leiden 1967. Al-Ya'qūbī, Ta'rīkh, Martijn T. Houtsma (ed.), Leiden 1883.

\section{Secondary sources}

Abel (2012): Armand Abel, "Dār al-Ḥarb”, in: Encyclopaedia of Islam² http://dx.doi.org/10.1163/ 1573-3912_islam_SIM_1700 (last accessed 6 November 2017).

Adams (1986): William Yewdale Adams, Ceramic Industries of Medieval Nubia (Memoirs of the UNESCO Archaeological Survey of Sudanese Nubia 1), Lexington.

Adams (2010): William Yewdale Adams, Qasr Ibrim. The Earlier Medieval Period (EES Excavation Memoirs 89), London.

Adams (2013): William Yewdale Adams, "Qasr Ibrim. Connecting the dots", in: Jacques van der Vliet and Joost L. Hagen (eds.), Qasr Ibrim. Between Egypt and Africa. Studies in Cultural Exchange. NINO Symposium, Leiden, 11-12 December 2009 (Egyptologische Uitgaven 26), Leuven, 45-63.

Ali/Dirar (1984): Mohamed Z. Ali and Hamid A. Dirar, "A microbiological study of Sudanese date wines", in: Journal of Food Science 49, 459-460. 
Arnold (2013): Felix Arnold, “The First Cataract as a border between two traditions of architecture?”, in: Dietrich Raue, Stephan Seidlmayer, and Philipp Speiser (eds.), The First Cataract of the Nile. One Region - Diverse Perspectives (Deutsches Archäologisches Institut Kairo. Sonderschrift 36), Berlin, 5-8.

Balog (1973): Paul Balog, "Poids et estampilles en verre et poids en bronze musulmans du Musée d'art et d'histoire de Genève”, in: Genava 21, 297-311.

Balog (1976): Paul Balog, Umayyad, 'Ābbasid, and Țülūnid Glass Weights and Vessel Stamps, New York.

Bailey (1998): Donald M. Bailey, Excavations at el-Ashmūnein. V: Pottery, Lamps and Glass of the Late Roman and Early Arab Periods, London.

Ballet/Vichy (1992): Pascale Ballet and Michèle Vichy, "Artisanat de la céramique dans l'Égypte hellénistique et romaine. Ateliers du Delta, d’Assouan et de Kharga”, in: Cahiers de la Céramique Egyptienne 3, 109-119.

Becker (1906): Carl Heinrich Becker, Papyri Schott-Reinhardt. I: Einführung in das Verständnis der Urkunden (Veröffentlichungen aus der Heidelberger Papyrus-Sammlung 3), Heidelberg, $15-56$.

Beckh (2013): Thomas Beckh, Zeitzeugen aus Ton. Die Gebrauchskeramik der Klosteranlage Deir el-Bachît in Theben-West (Oberägypten) (Deutsches Archäologisches Institut Kairo.

Sonderschrift 37), Berlin.

Beshir (1975): Beshir I. Beshir, "New light on Nubian Fatimid relations", in: Arabica 22.1, 15-24.

Bonner (2012): Michael Bonner, "Commerce and migration in Arabia before Islam. A brief history of a long literary tradition", in: Behrad Aghaei and Mohammad R. Ghanoonparvar (eds.), Iranian Languages and Culture. Essays in Honor of Gernot Ludwig Windfuhr, Malibu, 65-89.

Booth (2013): Phil Booth, "The Muslim conquest of Egypt reconsidered”, in: Constantin Zuckerman (ed.), Constructing the Seventh Century (Travaux et Mémoires 17), Paris, 639-670.

Bousquet (1996): Bernard Bousquet, Tell-Douch et sa région. Géographie d'une limite de milieu à une frontière d'Empire (Documents de fouilles de l'IFAO 31), Cairo.

Bowman (1978): Alan K. Bowman, "The military occupation of Upper Egypt in the reign of Diocletian", in: Bulletin of the American Society of Papyrologists 15, 25-38.

Brennan (1989): Peter Brennan, "Diocletian and Elephantine. A closer look at Pacocke's puzzle $($ IGRR 1.1291 = SB 5.8394)", in: Zeitschrift für Papyrologie und Epigraphik 76, 193-205.

Bruning (2018): Jelle Bruning, The Rise of a Capital. Al-Fusțāt and Its Hinterland, 18/639-132/750 (Islamic History and Civilization. Studies and Texts 153), Leiden 2018.

Brunsch (1994): Wolfgang Brunsch, "Koptische und griechische Inschriften aus Alexandria", in: Wiener Zeitschrift für die Kunde des Morgenlandes 84, 9-34.

Butler (1902): Alfred J. Butler, The Arab Conquest of Egypt and the Last Thirty Years of Roman Dominion, Oxford.

Cahen (2012): Claude Cahen, “Dhimma”, in: Encyclopaedia of Islam². http://dx.doi.org/10.1163/1573-3912_islam_SIM_1823 (last accessed 23 May 2019).

Casson (1990): Lionel Casson, “New light on maritime loans: P.Vindob. G 40822”, in: Zeitschrift für Papyrologie und Epigraphik 84, 195- 206.

Christides (1992): Vassilios Christides, "Nubia and Egypt from the Arab invasion of Egypt until the end of the Umayyads", in: Charles Bonnet (ed.), Études nubiennes. Actes du VII Congrès International d'Études nubiennes, 3-8 septembre 1990 vol. I, Genf, 341-356.

Christides (2012): Vassilios Christides, "Mișr b) Islamic Egypt. The conquest of Egypt”, in: Encyclopaedia of Islam², http://dx.doi.org/10.1163/1573-3912_islam_COM_0755 (last accessed 23 May 2019).

Cooper (2014): John P. Cooper, The Medieval Nile. Route, Navigation, and Landscape in Islamic Egypt, Cairo. 
Cottier (2010): Michel Cottier, "The customs districts of Roman Egypt", Proceedings of the $25^{\text {th }}$ International Congress of Papyrology in Ann Arbor 2007, Ann Arbor, 141-148.

Darling (2015): Linda T. Darling, “Customs dues, historical”, in: Encyclopaedia of Islam³. http://dx. doi.org/10.1163/1573-3912_ei3_COM_27349 (last accessed 23 May 2019).

De Romanis (2012): Federico De Romanis, “Playing Sudoku on the verso of the 'Muziris Papyrus.' Pepper, malabathron and tortoise shell in the cargo of the Hermapollon", in: Journal of Ancient Indian History 27, 75-101.

Dijkstra (2008): Jitse H. F. Dijkstra, Philae and the End of Ancient Egyptian Religion. A Regional Study of Religious Transformation (298-642 CE) (Orientalia Lovaniensia Analecta 173), Leuven, Paris, and Dudley, MA.

Drexhage (1994): Hans-Joachim Drexhage, “Einflüsse des Zollwesens auf den Warenverkehr im römischen Reich. Handelshemmend oder handelsfördernd?", in: Münstersche Beiträge zur Antiken Handelsgeschichte 13.2, 1-15.

Drexhage (2001): Hans-Joachim Drexhage, "Nochmals zu den Komposita mit -pōlēs und -pratēs im hellenistischen Ägypten”, in: Münstersche Beiträge zur Antiken Handelsgeschichte 20.1, $1-14$.

Dunn (1993): Archibald Dunn, "The kommerkiarios, the apotheke, the dromos, the vardarios, and the west", in: Byzantine and Modern Greek Studies 17, 3-24.

Effland (1999): Andreas Effland, "Zur Geschichte der Kopten im Raum Edfu. Teil 2: Die Festung der zwei Tore - Qal'at al-Babên", in: Kemet 8.3, 45-50.

Effland (2008): Andreas Effland, “Die befestigte Anlage Qal'at al-Babên nach den Berichten früher Ägyptenreisender”, in: Wolfgang Waitkus (ed.), Diener des Horus. Festschrift für Dieter Kurth zum 65. Geburtstag (Aegyptiaca Hamburgensia 1), Gladbeck, 83-92.

Emery (1938): Walter B. Emery, The Royal Tombs of Ballana and Qustul (Mission archéologique de Nubie 1929-1934), Cairo.

Forand (1966): Paul G. Forand, "Notes on 'ušr and maks", in: Arabica 13.2, 137-141.

Forand (1972): Paul G. Forand, "Early Muslim relations with Nubia”, in: Der Islam 48, 111-121.

Fraenkel (1982): Siegmund Fraenkel, Die aramäischen Fremdwörter im Arabischen, Hildesheim and New York [reprint of 1886 edition].

Fraser (1991): Peter M. Fraser, “Arab conquest of Egypt”, in: Aziz S. Atiya (ed.), The Coptic Encyclopaedia, New York, vol. I, 183-189.

Gascoigne (2005): Alison L. Gascoigne, "Dislocation and continuity in early Islamic provincial urban centres. The example of Tell Edfu", in: Mitteilungen des Deutschen Archäologischen Instituts Abteilung Kairo 61, 153-189.

Gascoigne/Rose (2010): Alison L. Gascoigne and Pamela J. Rose, "Fortification, settlement and ethnicity in southern Egypt", in: Paolo Matthiae et al. (eds.), Proceedings of the $6^{\text {th }}$ International Congress on the Archaeology of the Ancient Near East, Wiesbaden, vol. III, 45-54.

Gascou/Worp (1982): Jean Gascou and Klaas A. Worp, "Problèmes de documentation apollinopolite", in: Zeitschrift für Papyrologie und Epigraphik 49, 83-95.

Gempeler (1992): Robert D. Gempeler, Elephantine. X: Die Keramik römischer bis früharabischer Zeit (Archäologische Veröffentlichungen des Deutschen Archäologischen Instituts Abteilung Kairo 43), Mainz.

Goitein (1967): Salomon D. Goitein, A Mediterranean Society. The Jewish Communities of the Arab World as Portrayed in the Documents of the Cairo Geniza. I: Economic Foundations, Berkeley, Los Angeles, and London.

Gonis (2000): Nikolaos Gonis, "Two fiscal registers from early Islamic Egypt. P.Vatic.Aphrod. 13, SB XX 14701", in: The Journal of Juristic Papyrology 30, 21-29.

Gonis (2008): Nikolaos Gonis, “SB VI 8986 and Heraclius' sons”, in: Zeitschrift für Papyrologie und Epigraphik 166, 199-202. 
Grossmann/Jaritz (1974): Peter Grossmann and Horst Jaritz, "Ein Besuch in der Festung von Qal'at al-Babên in Oberägypten", in: Mitteilungen des Deutschen Archäologischen Instituts Kairo 30, $199-214$.

Grossmann (1991): Peter Grossmann, “Qal'at al-Bâbayn”, in: Aziz S. Atiya (ed.), The Coptic Encyclopedia, New York, vol. VII, 2035-2036.

Haldon (1990): John F. Haldon, Byzantium in the Seventh Century. The Transformation of a Culture, Cambridge.

Harrauer/Sijpesteijn (1985): Hermann Harrauer and Pieter Sijpesteijn, "Ein neues Dokument zu Roms Indienhandel. P.Vindob. G 40822", in: Anzeiger der Österreichischen Akademie der Wissenschaften. Philosophisch-Historische Klasse 122, 124-155.

El-Hawary (1930): Hassan M. El-Hawary, "The most ancient Islamic monument known dated A.H. 31 (A.D. 652), from the time of the third Calif 'Uthman," in: Journal of the Royal Asiatic Society of Great Britain and Ireland 62.2, 321-333.

Hendy (1993): Michael F. Hendy, "From Antiquity to the Middle Ages. Economic and monetary aspects of the transition”, in: De la Antigüedad al medievo (siglos IV-VIII). III Congreso de Estudios Medievales, León, 323-360.

Hinds/Sakkout (1981): Martin Hinds and Hamdi Sakkout, "A letter from the governor of Egypt to the King of Nubia and Muqurra concerning Egyptian-Nubian relations in 141/758", in: Wadād Al-Qādī (ed.), Studia Arabica et Islamica. Festschrift for Ihsan Abbas on his Sixtieth Birthday, Beirut, 209-229.

Hinz (1970): Walther Hinz, Islamische Masse und Gewichte, umgerechnet ins metrische System (Handbuch der Orientalistik. Eränzungsband 1.1), 2nd edition, with additions, Leiden, Köln.

Hope (2000): Colin A. Hope, "Kegs and flasks from the Dakhleh Oasis", in: Cahiers de la Céramique Egyptienne 6, 189-234.

Jakab (2009): Éva Jakab, Risikomanagement beim Weinkauf. Periculum und Praxis im Imperium Romanum, München. DOI: 10.4000/books.chbeck.1146 (last accessed 15 August 2017).

Jakobielski/Van der Vliet (2011): Stefan Jakobielski and Jacques van der Vliet, "From Aswān to Dongola. The epitaph of Bishop Joseph (died A.D. 668)," in: Adam tajtar and Jacques van der Vliet (eds.), Nubian Voices. Studies in Christian Nubian Culture (The Journal of Juristic Papyrology. Supplement 15), Warsaw, 15-35.

Jördens (2009): Andrea Jördens, Statthalterliche Verwaltung in der römischen Kaiserzeit. Studien zum praefectus Aegypti (Historia Einzelschriften 175), Stuttgart.

Kaegi (1998): Walter Kaegi, “Egypt on the eve of the Muslim conquest”, in: Carl F. Petry (ed.), The Cambridge History of Egypt. I: Islamic Egypt 640-1517, Cambridge, 34-61.

Keenan (1990): James G. Keenan, "Evidence for the Byzantine army in the Syene papyri”, in: Bulletin of the American Society of Papyrologists 27, 139-150.

Kennedy (2008): Hugh Kennedy, The Great Arab Conquests. How the Spread of Islam Changed the World We Live In, London.

Khadduri (2012a): Majid Khadduri, "Hudna", in: Encyclopaedia of Islam². http://dx.doi.org/10.1163/1573-3912_islam_SIM_2932 (last accessed 22 May 2019).

Khadduri (2012b): Majid Khadduri, “Ṣulh", in: Encyclopaedia of Islam². http://dx.doi.org/10.1163/ 1573-3912_islam_SIM_7175 (last accessed 22 May 2019).

Khan (2013): Geoffrey Khan, “The medieval Arabic documents from Qasr Ibrim”, in: Jacques van der Vliet and Joost L. Hagen (eds.), Qasr Ibrim. Between Egypt and Africa. Studies in Cultural Exchange. NINO Symposium, Leiden, 11-12 December 2009 (Egyptologische Uitgaven 26), Leiden, 145-156.

Kheir (1989): El-Hag H. M. Kheir, “A contribution to a textual problem. Ibn Sulaym al-Aswāni’s Kitāb Akhbār al-Nūba wa-l-Maqurra wa-l-Beja wa-l-Nīl", in: Arabica 36, 36-80. 
Kruit/Worp (2000): Nico Kruit and Klaas Worp, "Geographical jar names. Towards a multi-disciplinary approach", in: Archiv für Papyrusforschung und verwandte Gebiete 46.1, 65-146.

Laiou (2002): Angeliki E. Laiou, "Exchange and trade, seventh-twelfth centuries", in: Angeliki E. Laiou (ed.), The Economic History of Byzantium. From the Seventh through the Fifteenth Century (Dumbarton Oaks Studies 39), Dumbarton Oaks, 697-770.

Laiou/Morrisson (2007): Angeliki E. Laiou and Cecile Morrisson, The Byzantine Economy (Cambridge Medieval Textbooks), Cambridge.

Lecuyot/Pierrat-Bonnefois (2004): Guy Lecuyot and Geneviève Pierrat-Bonnefois, “Corpus de la céramique de Tôd. Fouilles 1980-1983 et 1990”, in: Cahiers de la Céramique Egyptienne 7, $145-207$.

Masson et al. (2012): Aurélia Masson, Mohamed Naguib, and Mahmoud Shafey "Overview of the ceramic productions from the Luxor town mound", in: Bulletin de Liaison de la Céramique Égyptienne 23, 125-145.

Maxfield (2000): Valerie A. Maxfield, "The deployment of the Roman auxilia in Upper Egypt and the Eastern Desert during the Principate", in: Géza Alföldy, Brian Dobson, and Werner Eck (eds.), Kaiser, Heer und Gesellschaft in der Römischen Kaiserzeit. Gedenkschrift für Eric Birley (Heidelberger althistorische Beiträge und epigraphische Studien 31), Stuttgart, 407-442.

Miles (1963): George C. Miles, Contributions to Arabic Metrology. II: Early Arabic Glass Weights and Measure Stamps in the Benaki Museum, Athens, and the Peter Ruthven Collection, Ann Arbor and New York.

Monneret de Villard (1927): Ugo Monneret de Villard, Il Monastero di S. Simeone presso Aswān. I: Descrizione Archeologica, Milan.

Morelli (1996): Federico Morelli, Olio e retribuzioni nell'Egitto tardo (V-VIII d.C.), Florence.

Morelli (2010): Federico Morelli, “Consiglieri e comandanti. I titoli del governatore arabo d'Egitto symboulos e amîr”, in: Zeitschrift für Papyrologie und Epigraphik 173, 158-166.

Morelli (2011): Federico Morelli, "Dal Mar Rosso ad Alessandria. Il verso (ma anche il recto) del 'papiro di Muziris' (SB XVIII 13167)”, in: Tyche. Beiträge zur Alten Geschichte, Papyrologie und Epigraphik 26, $199-233$.

Neef/Podsiadlowski (2012-2013): Reinder Neef and Viola Podsiadlowski, “Archaeobotany on Elephantine Island", in: Felix Arnold et al., Report on the Excavations at Elephantine by the German Archaeological Institute and the Swiss Institute from Autumn 2012 to Spring 2013, 17-18, https://www.dainst.org/projekt/-/project-display/25953 (last accessed on 26.11.2018).

Noth (1973): Albrecht Noth, "Zum Verhältnis von kalifaler Zentralgewalt und Provinzen in Umayyadischer Zeit. Die 'șulḥ'- “anwa'-Traditionen für Ägypten und den Iraq”, in: Die Welt des Islam 14/1-4, 150-162.

Obłuski (2008): Artur Obłuski, "The formation of the Nobadian state. Social changes in Lower Nubia in Late Antiquity", in: Wtodzimierz Godlewski and Adam tajtar (eds.), Between the Cataracts. Proceedings of the 11th International Conference for Nubian Studies, Warsaw University, 27 August-2 September 2006 (PAM Suppl. Ser. II), Warsaw, 607-617.

Obłuski (2013): Artur Obłuski, "Dodekaschoinos in Late Antiquity. Ethnic Blemmyes vs. political Blemmyes and the arrival of Nobades", in: Der Antike Sudan 24, 141-147.

Payne Smith (1903): Jessie Payne Smith, A Compendious Syriac Dictionary, Oxford.

Pierrat (1991): Geneviève Pierrat, "Essai de classification de la céramique de Tôd de la fin du VII siècle au début du XIII siècle ap. J.-C.”, in: Cahiers de la Céramique Egyptienne 2, 145-204.

Plumley (1975): Jack Martin Plumley, “An eighth-century Arabic letter to the King of Nubia”, in: Journal of Egyptian Archaeology 61, 241-245.

Plumley/Adams (1974): Jack Martin Plumley and William Yewdale Adams, "Qașr Ibrîm, 1972", in: Journal of Egyptian Archaeology 60, 212-238. 
Porten et al. (1996): Bezalel Porten et al. (eds.), The Elephantine Papyri in English. Three Millennia of Cross-Cultural Continuity and Change (Documenta et monumenta Orientis antique. Studies in Near Eastern archaeology and civilisation 22), Leiden, New York, and Köln.

Rathbone (2000): Dominic Rathbone, "The Muziris papyrus (SB XVIII 13167). Financing Roman trade with India”, in: Mohammed Abd-el-Ghani, Soheir Z. Bassiouni, Wessam A. Farag (eds.), Alexandrian Studies II. In Honour of Mostafa el Abbadi, Alexandria 2000, 39-50.

Rodziewicz (1976): Mieczystaw Rodziewicz, La céramique romaine tardive d'Alexandrie (Alexandrie I), Warsaw.

Rodziewicz (2005): Mieczysław Rodziewicz, Elephantine XXVII: Early Roman Industries on Elephantine (Archäologische Veröffentlichungen des Deutschen Archäologischen Instituts Abteilung Kairo 107), Mainz.

Ruffing (1999): Kai Ruffing, Weinbau im Römischen Ägypten (Pharos 12), St. Katharinen.

Ruffing (2008): Kai Ruffing, Die berufliche Spezialisierung in Handel und Handwerk. Untersuchungen zu ihrer Entwicklung und zu ihren Bedingungen in der römischen Kaiserzeit im östlichen Mittelmeerraum auf der Grundlage griechischer Inschriften und Papyri (Pharos 24), Rahden.

Ruffing (2013): Kai Ruffing, "The trade with India and the problem of agency in the economy of the Roman Empire", in: Silvia Bussi (ed.), Egitto dai Faragoni agli Arabi. Atti del convegno "Egitto: amministrazione, economia, società, cultura dai faraoni agli arabi, Milano, Università degli Studi, 7-9 gennaio 2013 (Studie ellenistici 1), Pisa, 199-210.

Sato (2012): T. Sato, “'Ushr”, in: Encyclopaedia of Islam². http://dx.doi.org/10.1163/1573-3912_ islam_COM_1309 (last accessed 23 May 2019).

Schacht (2012): Joseph Schacht, “'Ahd”, in: Encyclopaedia of Islam². http://dx.doi.org/10.1163/ 1573-3912_islam_SIM_0371 (last accessed 22 May 2019).

Schmidt (2018): Stefanie Schmidt, “P.Bas. II 69 and 70. A look behind the text”, in: Archiv für Papyrusforschung und verwandte Gebiete 64/2, 324-342.

Schmidt (forthcoming): Stefanie Schmidt "The Frontier Zone at the First Cataract before and at the time of the Muslim conquest (5th to 7th centuries)", in: Jelle Bruning, Janneke De Jong, and Petra M. Sijpesteijn, (eds.), Incorporating Egypt. From Constantinople to Baghdad, 500-1000 $C E$, Cambridge.

Seignobos (2010): Robin Seignobos "La frontière entre le bilād al-Islām et le bilād al-Nūba. Enjeux et ambiguïtés d'une frontière immobile (VII $-\mathrm{XII}{ }^{\mathrm{e}}$ siècle)", in: Afriques [online], 2 (2010), http://afriques.revues.org/800 (last accessed 25 July 2017).

Seignobos (forthcoming): Robin Seignobos, “L’Égypte et la Nubie à l'époque médiévale. Élaboration et transmission des savoirs historiographiques”, PhD dissertation, University of Paris 2016.

Sijpesteijn (2007): Petra M. Sijpesteijn, "The Arab conquest of Egypt and the beginning of Muslim rule”, in: Roger S. Bagnall (ed.), Egypt in the Byzantine World, 300-700, Cambridge, 437- 459 .

Sijpesteijn (2010): Petra M. Sijpesteijn, "Multilingual archives and documents in post-conquest Egypt”, in: Arietta Papaconstantinou (ed.), The Multilingual Experience in Egypt, from the Ptolemies to the 'Abbāsids, Burlington, 105-124.

Sijpesteijn (2013): Petra M. Sijpesteijn, Shaping a Muslim State. The World of a Mid-Eighth-Century Egyptian Official (Oxford Studies in Byzantium), Oxford.

Sijpesteijn (1987): Pieter J. Sijpesteijn, Customs Duties in Graeco-Roman Egypt (Studia Amstelodamensia ad epigraphicam, ius antiquum et papyrologicam pertinentia XVII), Zutphen.

Sijpesteijn/Worp (1977): Pieter J. Sijpesteijn and Klaas A. Worp, “Chronological notes”, in: Zeitschrift für Papyrologie und Epigraphik 26, 267-286. 
Speidel (2016): Michael A. Speidel, "Fernhandel und Freundschaft zu Roms 'Amici' an den Handelsrouten nach Südarabien und Indien", in: Orbis Terrarum 14, 155-193.

Strange Burke (2007): Katherine Strange Burke, Archaeological Texts and Contexts on the Red Sea. The Sheikh's House at Quseir al-Qadim, vol. I, PhD dissertation, University of Chicago.

Thür (1987): Gerhard Thür, "Hypotheken-Urkunde eines Seedarlehens für eine Reise nach Muziris und Apographe für die Tetarte in Alexandria (zu P.Vindob. G 40.822)", in: Tyche. Beiträge zur Alten Geschichte, Papyrologie und Epigraphik 2, 229-245.

Van der Vliet (2013): Jacques van der Vliet, "Christus imperat. An ignored Coptic dating formula”, in: Youhanna Nessim Yousef and Samuel Moawad (eds.), From Old Cairo to the New World. Coptic Studies Presented to Gawdat Gabra on the Occasion of his Sixty-Fifth Birthday (Colloquia Antiqua 9), Leuven, Paris, and Walpole, MA, 173-184.

de Vogüé (1883): Melchior de Vogüé, “Inscriptions palmyréniennes inédites. Un tarif sous l'Empire romain", in: Journal Asiatique, août/septembre 1883, 149-183.

Wallace (1969): Sherman LeRoy Wallace, Taxation in Egypt. From Augustus to Diocletian, New York [reprint of 1938 edition].

Webb (2016): Peter Webb, Imagining the Arabs. Arab Identity and the Rise of Islam, Edinburgh.

Wild/Wild (2014): John P. Wild and Felicity Wild, "Qasr Ibrim. New perspectives on the changing textile culture of Lower Nubia”, in: Elisabeth R. O'Connell (ed.), Egypt in the First Millenium $A D$. Perspectives from New Fieldwork, Leuven et al., 71-80.

Williams (forthcoming): Williams, Gregory, A Center on the Edge: Early Islamic Pottery from Aswan, $\mathrm{PhD}$ dissertation.

Young (1997): Gary K. Young, "The customs-officer at the Nabataean port of Leuke Kome (Periplus Maris Erythraei 19)", in: Zeitschrift für Papyrologie und Epigraphik 119, 266-268.

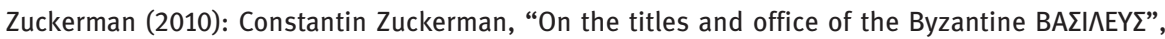
in: [AA. VV.] (ed.), Mélanges Cécile Morrisson (Travaux et Mémoirs 16), Paris, 865-890. 